\title{
Identification and Oxidation Products of Gluconobacter Strains Isolated from Fruits and Flowers in Thailand
}

\author{
Jintana Kommanee \\ Department of Biochemistry and Microbiology \\ Faculty of Pharmaceutical Sciences \\ Chulalongkorn University, Bangkok 10330, Thailand \\ Tel: 66-2218-8376 E-mail: jintana.kommanee@gmail.com
}

Somboon Tanasupawat (Corresponding author)

Department of Biochemistry and Microbiology

Faculty of Pharmaceutical Sciences

Chulalongkorn University, Bangkok 10330, Thailand

Tel: 66-2218-8376 E-mail: Somboon.T@chula.ac.th

\section{Pattaraporn Yukphan}

BIOTEC Culture Collection, BIOTEC Central Research Unit

National Centre for Genetic Engineering and Biotechnology

National Science and Technology Development Agency

113 Thailand Science Park, Phaholyothin Road, Pathumthani 12120, Thailand

Tel: 66-2564-6700Ｅ-mail: pattaraporn@biotec.or.th

\section{Duangtip Moonmangmee}

Department of Microbiology, Faculty of Science

King Mongkut's University of Technology Thonburi

Bangkok 10140, Thailand

Tel: 66-2470-9571 E-mail: duangtip.moo@kmutt.ac.th

$$
\text { Nuttha Thongchul }
$$

The Institute of Biotechnology and Genetic Engineering

Chulalongkorn University, Bangkok 10330, Thailand.

Tel: 66-2218-0852Ｅ-mail: nuttha.t@chula.ac.th

\author{
Yuzo Yamada \\ BIOTEC Culture Collection, BIOTEC
}

Central Research Unit, National Centre for Genetic Engineering and Biotechnology

National Science and Technology Development Agency

113 Thailand Science Park, Phaholyothin Road, Pathumthani 12120, Thailand

$\&$

JICA Senior Overseas Volunteer, Japan International Cooperation Agency (JICA)

Shibuya-ku, Tokyo 151-8558, Japan 
$\&$

\author{
Professor Emeritus, Shizuoka University
}

Shizuoka 422-8529, Japan

Tel: 81-54-635-2316 E-mail: yamada-yuzo@mub.biglobe.ne.jp

$\begin{array}{lc}\text { Received: October 20, } 2011 & \text { Accepted: November 4, } 2011 \quad \text { Published: January 1, } 2012 \\ \text { doi:10.5539/ijb.v4n1p69 } & \text { URL: http://dx.doi.org/10.5539/ijb.v4n1p69 }\end{array}$

The research is financed by the Graduate Institute of Science and Technology, TGIST, 2007, National Science and Technology Development Agency, Thailand and the Faculty of Pharmaceutical Sciences Research Fund, 2008, Chulalongkorn University, Thailand

\begin{abstract}
The intent of the study is to identify and screen the oxidative products of acetic acid bacteria (AAB) from fruits and flowers in Thailand. Twenty-four isolates of AAB isolated from 22 fruit samples and two flower samples were grouped and identified at the species level in the genus Gluconobacter on the basis of their phenotypic and chemotaxonomic characteristics including molecular techniques. They were divided into four groups and identified as G. frateurii (Group 1, four isolates), G. japonicus (Group 2, two isolates), G. thailandicus (Group 3, 6 isolates), and G. oxydans (Group 4, 12 isolates) using 16S-23S rRNA gene internal transcribed spacer regions (ITS) restriction analysis and 16S-23S rRNA gene ITS phylogenetic analysis. All isolates were screened for dihydroxyacetone (DHA) and L-sorbose production. The test isolates produced DHA ranged from 25.24 to 42.52 $\mathrm{g} / \mathrm{l}$ at $30^{\circ} \mathrm{C}$. G. oxydans isolate PHD-27 produced a large amount of DHA. The test isolates produced L-sorbose ranged from 15.77 to $39.68 \mathrm{~g} / 1$ at $30^{\circ} \mathrm{C}$. G. frateurii isolate PHD-30 produced a largest amount of L-sorbose.
\end{abstract}

Keywords: Acetic acid bacteria, dihydroxyacetone, L-sorbose, Gluconobacter, 16S-23S rRNA gene ITS

\title{
1. Introduction
}

Strains of the genus Gluconobacter are classified in the family Acetobacteraceae, $\alpha$-Proteobacteria. They distributed in sugar and alcoholic materials such as flowers, fruits, beer, wine, cider, vinegar, soft drinks and souring fruit juices (Gupta et al., 2001; Battey \& Schaffner, 2001). The genus Gluconobacter comprises twelve species; G. oxydans, G. cerinus, G. frateurii, G. thailandicus, G. albidus, G. sphericus, G. kondonii, G. japonicus, G. roseus, G. kanchanaburiensis, G. wancherniae and G. nephelii (Kersters et al., 2006; Kommanee et al., 2011; Malimas et al., 2009, Skerman et al., 1980; Tanasupawat et al., 2004; Yukphan et al., 2010).

Gluconobacter strains generally produced acid and showed an efficient ketogenesis from polyhydroxyalcohols via a single-step oxidation. They are considerable interest for the biotechnological industry for dihydroxyacetone (DHA), L-sorbose, D-gluconic acid, 2-keto-D-gluconic acid, 5-keto-D-gluconic acid, D-tagatose, D-fructose, etc. production. (Adachi et al., 2003; Manzoni et al., 2001; Moonmangmee et al., 2000).

DHA is the oxidative product of glycerol while L-sorbose is from D-sorbitol that is industrially produced by G. oxydans (Deppenmeier et al., 2002; Salusjärvi et al., 2004 ). The DHA is commonly used as a tanning agent in the cosmetics industry and constitutes a building block for several chemical compounds, e.g., methotrexate, which is used in the chemotherapeutical treatment of cancer patients (Claret et al., 1994; Mishra et al., 2008). L-Sorbose has been used as an intermediate for synthesis of vitamin C by the Reichstein process (Hancock and Viola, 2002). L-Sorbose is produced from D-sorbitol by D-sorbitol dehydrogenase, which is bound to the cell membrane (Kim et al., 1999; Shinagawa et al., 1982).

The aim of this study was to identify Gluconobacter strains isolated from fruits and flowers in Thailand based on 16S-23S rRNA gene ITS restriction analysis and 16S-23S rRNA gene ITS sequence along with the phenotypic and chemotaxonomic characterization including the screening of their oxidative products.

\section{Materials and Methods}

\subsection{Isolation of acetic acid bacteria}

AAB were isolated from fruits (22 samples) and flowers (two samples) collected in Thailand by an enrichment culture approach using glucose/ethanol/yeast extract (GEY) medium (Kommanee et al., 2008) (Table 1). An isolation source was incubated at $\mathrm{pH} 4.5$ and $30^{\circ} \mathrm{C}$ for $3-5$ days in a liquid medium. When microbial growth was 
found, the culture was streaked onto a GEY-agar plate containing $0.3 \% \mathrm{CaCO}_{3}(\mathrm{w} / \mathrm{v})$ (Yamada et al., 1976). $\mathrm{AAB}$ were selected as an acid-producing bacterial strain that formed a clear zone around the colony on the agar plate.

\subsection{Phenotypic and chemotaxonomic characterization of $A A B$}

Phenotypic characterization was carried out by incubating test strains at $30^{\circ} \mathrm{C}$ and $\mathrm{pH} 6.8$ for two days on glucose/yeast extract/peptone/glycerol (GYPG) agar (Kommanee et al., 2008). For Gram stain of bacterial cells was performed as described by Hucker \& Conn, 1923. Physiological and biochemical characterizations were determined as previously reported (Asai et al., 1964; Gosselé et al., 1980). The cells of isolates grown in GYPG broths on a rotary shaker $(150-200 \mathrm{rpm})$ at $30^{\circ} \mathrm{C}$ for $24 \mathrm{~h}$ were collected for the chemotaxonomic characterization. Ubiquinone was analyzed by the method of Yamada et al. (1968) and Tamaoka et al. (1983).

\subsection{Restriction analysis of 16S-23S rRNA gene internal transcribed spacer regions (ITS)}

16S-23S rRNA gene ITS PCR amplification was made by using the two primers, 5'TGC GG(C/T) TGG ATC ACC TCC T-3' (position 1522-1540 on 16S rRNA by the Escherichia coli numbering system (Brosius et al., 1981) and 5' GTG CC(A/T) AGG CAT CCA CCG-3' (position 38-22 on 23S rRNA) (Trcek \& Teuber, 2002). The purified PCR products (715 bp) for Gluconobacter isolates were individually digested with restriction endonucleases Bst NI, MboII and MboI (New England BioLabs, Beverly, Massachusetts, USA) according to the manufacturer's instructions. The resulting reaction products were analyzed by $2.5 \%(\mathrm{w} / \mathrm{v})$ agarose gel electrophoresis developed at 100V for $40 \mathrm{~min}$ in 1x Tris-acetate running buffer (Malimas et al., 2009; Yukphan et al., 2004).

\subsection{Sequencing of 16S-23S rRNA gene ITS and phylogenetic analyses}

Chromosomal DNA was extracted by the method described by Saito \& Miura (1963). The extracted DNA was amplified for the 16S-23S rRNA gene ITS regions with two primers (Brosius et al., 1981), 1522F-16S and 38R-23S. The amplified 16S-23S rRNA gene ITS was directly sequenced with an ABI PRISM Big Dye Terminator V3.1 Cycle sequencing kit on an ABI PRISM model 310 Genetic Analyzer (Applied Biosystems, Foster, California, USA). For sequencing, the following four primers were used; 1522F, 38R, Talaf (5' AGA GCA CCT GCT TTG CAA 3') and Talar (5' ACC CCC TGC TTG CAA A 3').

Multiple sequence alignments were performed with a program CLUSTAL X (version 1.83) (Thompson et al., 1997). Gaps and ambiguous bases were eliminated from calculation. Distance matrices for the aligned sequences were calculated by the two-parameter method of Kimura (1980). A phylogenetic tree based on 16S-23S rRNA gene ITS sequences was constructed by the neighbor-joining method (Saitou \& Nei, 1987) with the program MEGA 4 (Tamura et al., 2007). The confidence values of individual branches in the phylogenetic tree were determined by using the bootstrap analysis (Felsenstein, 1985) based on 1,000 replications.

\subsection{Screening of strains producing DHA from glycerol}

Twenty-four isolates of Gluconobacter were cultivated in potato medium, which contained $10.0 \%$ potato extract, $0.5 \%$ glucose, $1.0 \%$ glycerol, $1.0 \%$ yeast extract and $1.0 \%$ peptone (all by w/v), at $30^{\circ} \mathrm{C}$ on a rotary shaker $(200$ $\mathrm{rpm}$ ) for $24 \mathrm{~h}$ and transferred to a DHA production medium containing $5 \%$ glycerol and $1 \%$ yeast extract at $\mathrm{pH}$ 5.0 (all by w/v) and cultivated at $30^{\circ} \mathrm{C}$ on a rotary shaker $(200 \mathrm{rpm})$ for four days. The quantitative analysis of DHA was made by diphenylamine reaction (Karklinya et al., 1982). The potential selected strain was cultivated in $10 \mathrm{ml}$ potato medium for $24 \mathrm{~h}$. One $\mathrm{ml}$ of the cultures $(0.5$ optical density at $600 \mathrm{~nm}$ ) was transferred to 200 $\mathrm{ml}$ DHA production medium and incubated at $30^{\circ} \mathrm{C}$ on a rotary shaker $(200 \mathrm{rpm})$ for $96 \mathrm{~h}$. An aliquot was taken every $12 \mathrm{~h}$ for biomass evolution and quantitative DHA production was analyzed by diphenylamine reaction.

\subsection{Screening of strains producing $L$-sorbose from D-sorbitol}

Twenty-four isolates of Gluconobacter were cultivated in potato medium at $30^{\circ} \mathrm{C}$ on a rotary shaker $(200 \mathrm{rpm})$ for $24 \mathrm{~h}$ and were transferred to L-sorbose production medium (Moonmangmee et al., 2000) incubated at $30^{\circ} \mathrm{C}$ on a rotary shaker $(200 \mathrm{rpm})$ for $48 \mathrm{~h}$. The quantitative analysis of L-sorbose was made by resorcinol reaction (Adachi et al., 2001). This assay was rapid and simple in determining the presence of ketoses as observed by the cherry-red color development. The sugar quantity could be estimated based on the standard graph of a series of known concentration of L-sorbose.

\section{Results and Discussion}

\subsection{Identification of isolates}

Twenty-four acetic acid bacteria were isolated from fruits and flowers collected in Thailand. They were Gram-negative, aerobic and rod-shaped. They produced catalase and grew on mannitol agar. They did not 
oxidize acetate and lactate and not grew on glutamate agar. They produced D-gluconate, 2-keto-D-gluconate and 5-keto-D-gluconate from D-glucose, but not 2,5-diketo-D-gluconate. Major ubiquinone was Q-10 (Table 2). They were assigned to the genus Gluconobacter (Kersters et al., 2006; Skerman et al., 1980; Tanasupawat et al., 2004) and were divided into four groups; Group 1 that contained four isolates of G. frateurii, Group 2 that contained two isolates of $G$. japonicus, Group 3 that contained six isolates of G. thailandicus and Group 4 that contained twelve isolates of $G$. oxydans.

Group 1 was composed of four isolates, PHD-30, PHD-31, PHD-66 and PHD-67 (Table 1). All the isolates produced dihydroxyacetone from glycerol and grew at $30^{\mathrm{C}} \mathrm{C}$. Some strains did not grow at $37{ }^{\circ} \mathrm{C}$. They produced acids from L-arabinose, D-galactose, D-glucose, meso-erythritol (weak), and D-xylose (weak) glycerol, maltose (weak), and sucrose but not from D-arabinose, dulcitol, D-fructose, lactose, D-mannose, D-mannitol, D-melibiose, L-rhamnose, raffinose, L-sorbose, and D-sorbitol. The isolates grown on D-arabitol, L-arabitol and meso-ribitol (weak) but not on meso-erythritol, being different from strains of G. oxydans and G. cerinus. Isolate PHD-30, a representative strain had $55.2 \mathrm{~mol} \%$ of DNA G+C content. The isolates showed almost the same phenotypic characteristics as G. frateurii NBRC $3264^{\mathrm{T}}$ (Table 2) (Yukphan et al., 2004; Kommanee et al., 2008). The isolates were located within the cluster of $G$. frateurii in the phylogenetic tree based on 16S-23S rRNA gene ITS sequences (Figure 1) and had $99.9 \%$ pair-wise 16S-23S rRNA gene ITS sequence similarity to the type strain of $G$. frateurii. Isolate PHD-30 gave the same restriction patterns as the type strain of G. frateurii when digested with $B s t \mathrm{NI}, M b o I I$ and $M b o$ I (Figure 2). From the data obtained above, all the isolates grouped into Group 1 were identified as $G$. frateurii.

Group 2 was composed of two isolates, PHD-28 and PHD-29 (Table 1). They produced acids from D-glucose and meso-erythritol (weak), and in some cases, from L-arabinose, D-galactose, glycerol, D-mannose, D-melibiose, sucrose and D-xylose. Some isolates produced acids weakly from D-arabinose, dulcitol, D-fructose, lactose and D-mannitol, but none produced acids from maltose, raffinose, L-rhamnose, L-sorbose or D-sorbitol. They grew on meso-erythritol, D-arabitol, L-arabitol (weak) and meso-ribitol. The isolates produced DHA weakly from glycerol. All the isolates were distinguished from $G$. frateurii by the ability to grow on meso-erythritol and produced acid weakly from raffinose. Isolates PHD-28, a representative isolate had 56.2 mol\% of DNA G+C content. They showed almost the same phenotypic characteristics as G. japonicus NBRC $3271^{\mathrm{T}}$ (Table 2) (Malimas et al., 2009). All isolates were located within the cluster of G. japonicus in the phylogenetic tree based on 16S-23S rRNA gene ITS sequences (Figure. 1) and had 99.8\% pair-wise 16S-23S rRNA gene ITS sequence similarity to the type strain of $G$. japonicus. Isolate PHD-28 gave the same restriction patterns as the type strain of G. japonicus when digested with Bst NI, MboII and MboI (Figure 2). From the data obtained above, all the isolates grouped into Group 2 were identified as G. japonicus.

Group 3 was composed of six isolates, PHD-11, PHD-21, PHD-22, PHD-36, PHD-39 and PHD-40 (Table 1). All isolates produced DHA from glycerol. They grew on D-arabitol, L-arabitol, meso-ribitol (weakly) and meso-erythritol, but not on dulcitol. They produced acids from L-arabinose, D-fructose, D-galactose, D-glucose, glycerol, D-mannitol (variable and weak), D-ribose, L-sorbose (weak), D-xylose and ethanol. In contrast, no acid production was found from maltose, D-mannose, melibiose, raffinose, L-rhamnose, D-sorbitol and sucrose. They grew on mannitol agar but not on glutamate agar. The isolates grow at $37^{\circ} \mathrm{C}$. Isolate PHD-21, a representative strain had $57.2 \mathrm{~mol} \%$ DNA G+C content. They showed almost the same phenotypic characteristics as the type strain of G. thailandicus (Table 2) (Tanasupawat et al., 2004; Kommanee et al., 2008). All isolates were located within the cluster of $G$. thailandicus in the phylogenetic tree based on 16S-23S rRNA gene ITS sequences (Figure 1) and had $99.9 \%$ pair-wise 16S-23S rRNA gene ITS sequence similarity to the type strain of $G$. thailandicus. Isolate PHD-11 gave the same restriction patterns as the type strain of G. thailandicus when digested with BstNI (Figure 2). From the data obtained above, all the isolates grouped into Group 3 were identified as $G$. thailandicus.

Group 4 was composed of 12 isolates, PHD-10, PHD-19, PHD-20, PHD-27, PHD-41, PHD-43, PHD-55, PHD-59, PHD-60, PHD-81, PHD-82 and PHD-88 (Table 1). They produced acid from L-arabinose, D-fructose, D-galactose, D-glucose, glycerol, D-mannitol (weak), D-ribose (weak), L-sorbose, maltose and D-xylose. In contrast, no acid production was found from D-mannose, melibiose, raffinose, L-rhamnose, D-sorbitol and sucrose. They grew on D-glucose, D-fructose, D-mannitol, D-sorbitol, glycerol, meso-ribitol (weak) and maltose but not on sucrose, raffinose, dulcitol, D-arabitol and L-arabitol. They grew on mannitol agar but not on glutamate agar. The isolates produced acetylmethyl carbinol from lactate. They showed almost the same phenotypic characteristics as the type strain of G. oxydans (Table 2) (Yukphan et al., 2004; Kommanee et al., 2008). All isolates were located within the cluster of $G$. oxydans NBRC $14819^{\mathrm{T}}$ in the phylogenetic tree based on 16S-23S rRNA gene ITS sequences (Figure 1) and had 99.9\% pair-wise 16S-23S rRNA gene ITS sequence 
similarity to the type strain of G. oxydans. Isolate PHD-10 gave the same restriction patterns as the type strain of G. oxydans when digested with MboII (Figure 2). The restriction pattern of the isolate was distinguished from those of the type strains of G. roseus and G. sphaericus when digested with MboI. From the data obtained above, all the isolates grouped into Group 4 were identified as G. oxydans.

In this study, four isolates were identified as G. frateurii, two isolates were as G. japonicus, six isolates were as G. thailandicus and 12 isolates were as G. oxydans. There were distributed in fruits and flowers in Thailand (Table 1). Yamada et al. (1999) reported the isolates of G. oxydans and G. frateurii, and there were no the isolates of G. cerinus from the Indonesian sources. Tanaka et al. (1999) reported three species, G. cerinus, G. asaii, and G. frateurii as the low $\mathrm{G}+\mathrm{C}$ contents isolates and $\mathrm{G}$. oxydans as the high $\mathrm{G}+\mathrm{C}$ contents isolates from Japanese sources. Huong et al. (2007) identified 44 Thai Gluconobacter isolates and grouped into seven groups, but there were no G. japonicus and G. thailandicus strains. In Gluconobacter isolates from fruits, flowers and other materials collected in Thailand, Kommanee et al. (2008) identified 17 isolates as G. oxydans, 12 isolates as G. cerinus, nine isolates as G. frateurii, six isolates as G. thailandicus and one as an unidentified isolate.

From, this result the Gluconobacter isolates was successfully identified at the species level by the phenotypic and chemotaxonomic characterization including the 16S-23S rRNA gene ITS restriction analyses using BstNI, MboII and $\mathrm{MboI}$ and 16S-23S rRNA gene sequence were useful.

\subsection{Dihydroxyacetone production}

Twenty-four isolates of Gluconobacter were tested for the ability to produce DHA. Initial screening was tested based on the diphenylamine method. Production of DHA was observed by blue color development. The sugar quantity can be estimated based on the standard graph of a series of known concentration of DHA. It was found that the twenty-four isolates produced a large amount of DHA ranged from 25.24 to $42.52 \mathrm{~g} / 1$ at $30^{\circ} \mathrm{C}$ for four days (Table 1). Isolate PHD-27 identified as G. oxydans showed the highest DHA production reached to $42.52 \mathrm{~g} / 1$ and was therefore selected for DHA production.

In DHA production, it is clear that the DHA concentration increased with the decrease of glycerol. The DHA concentration reached the maximum of $44.1 \mathrm{~g} / \mathrm{l}$ at $30^{\circ} \mathrm{C}$ by conversion time of $84 \mathrm{~h}$ and generated DHA at a rate of $0.52 \mathrm{~g} / \mathrm{l} / \mathrm{hr}$ (Figure 3). Interestingly, the isolate PHD-27 showed good growth without any lag phase and produced DHA rapidly after the late log phase. The data suggested that $G$. oxydans isolate PHD-27 could produce DHA higher than the strain of $G$. oxydans improved by genetic engineering that produced DHA reached $30 \mathrm{~g} / \mathrm{l}$, while the wild type strains produced $18-25 \mathrm{~g} / \mathrm{l}$ of DHA from $50 \mathrm{~g} / \mathrm{l}$ glycerol (Kim et al., 1999). These data suggested that $G$. oxydans isolate PHD-27 suitable for using DHA production.

\subsection{L-sorbose production}

The twenty-four isolates of Gluconobacter were preliminary screened for their ability to produce L-sorbose using the resorcinol assay method. They produced a large amount of L-sorbose ranged from 15.77 to $39.68 \mathrm{~g} / 1$ at $30^{\circ} \mathrm{C}$ for $48 \mathrm{~h}$ (Table 1). The $\mathrm{pH}$ of the culture broth came down from 6.3 to 4.7 (data not shown). In the part of L-sorbose production, the fermentation efficiency and the fermentation rate by G. frateurii isolate PHD-30 was quite high, and the isolate rapidly oxidized D-sorbitol to L-sorbose at almost $100 \%$ within $24 \mathrm{~h}$ at $30^{\circ} \mathrm{C}$. However, the amount of produced L-sorbose was less than that $(50.0 \mathrm{~g} / 1$ by $\mathrm{G}$. frateurii isolate CHM54 for $48 \mathrm{~h})$ reported by Moonmangmee et al. (2000).

\section{Conclusion}

The present study revealed that 24 isolates from flowers and fruits collected in Thailand belonged to the genus Gluconobacter and were identified as G. frateurii, G. japonicus, G. thailandicus and G. oxydans routinely by phenotypic and chemotaxonomic characterizations, and finally by the 16S-23S rRNA gene ITS restriction analysis and the 16S-23S rRNA gene ITS phylogenetic analysis. All isolated Gluconobacter species produced DHA from glycerol and L-sorbose from D-sorbitol. Of the isolates, G. oxydans isolate PHD-27 and G. frateurii isolate PHD-30 produced a large amount of DHA and L-sorbose, respectively.

\section{References}

Adachi, O., Fujii, Y., Ghaly, M. F., Toyama, H., Shinagawa, E. \& Matsushita, K. (2001). Membrane-bound quinoprotein D-arabitol dehydrogenase of Gluconobacter suboxydans IFO 3257: a versatile enzyme for the oxidative fermentation of various ketoses. Bioscience Biotechnology and Biochemistry, 65, 2755-2762. http://dx.doi.org/10.1271/bbb.65.2755

Adachi, O., Moonmangmee, D., Toyama, H., Yamada, M., Shinagawa, E. \& Matsushita, K. (2003). New development in oxidative fermentation. Applied Microbiology and Biotechnology, 60, 643-653. 
applications. Journal of Molecular Microbiology and Biotechnology, 3, 445-456.

Asai, T., Iizuka, H. \& Komagata, K. (1964). The flagellation and taxonomy of genera Gluconobacter and Acetobacter with reference to the existence of intermediate strain. Journal of General and Applied Microbiology, 10, 95-126. http://dx.doi.org/10.2323/jgam.10.95

Battey, A. S. \& Schaffner, D. W. (2001). Modelling bacterial spoilage in cold-filled ready to drink beverages by Acinetobacter calcoaceticus and Gluconobacter oxydans. Journal of Applied Microbiology, 91, 237-247. http://dx.doi.org/10.1046/j.1365-2672.2001.01381.x

Biotechnology, 76, 553-559. http://dx.doi.org/10.1007/s00253-007-1003-z

Brosius, J., Dull, T. J., Sleeter, D. D. \& Noller, H. F. (1981). Gene organization and primary structure of a ribosomal RNA operon from Escherichia coli. Journal of Molecular Biology, 148, 107-127. http://dx.doi.org/10.1016/0022-2836(81)90508-8

Claret, C., Salmon, J., Romieu, C. \& Bories A. (1994). Physiology of Gluconobacter oxydans during dihydroxyacetone production from glycerol. Applied Microbiology and Biotechnology, 41, 359-365. http://dx.doi.org/10.1007/BF00221232

contents of DNA belonging to the genus Gluconobacter Asai 1935 (Acetobcteraceae). Bioscience Biotechnology and Biochemistry, 63, 989-992. http://dx.doi.org/10.1271/bbb.63.989

Deppenmeier, U., Hoffmeister, M. \& Prust, C. (2002). Biochemistry and biotechnological applications of Gluconobacter strains. Applied Microbiology and Biotechnology, 59, 1513-1533.

Felsenstein, J. (1985). Confidence limits on phylogenies: an approach using the bootstrap. Evolution, 39, 783-791. http://dx.doi.org/10.2307/2408678

Gätgens, C., Degner, U., Bringer-Meyer, S. \& Herrmann,U. (2007). Biotransformation of glycerol to dihydroxyacetone by recombinant Gluconobacter oxydans DSM 2343. Applied Microbiology and

Gosselé, F., Swings, J. \& De Ley, J. (1980). A rapid, simple and simultaneous detection of 2-keto, 5-keto- and 2,5-diketogluconic acid by thin layer chromatography in culture media of acetic acid bacteria. Zentralblatt für Bakteriologie Mikrobiologie und Hygiene I. Abt. Originale C, 1, 178-181.

Gupta, A., Singh, V. K., Qazi,G. N. \& Kumar, A. (2001). Gluconobacter oxydans: its biotechnological

Hancock, R. D. \& Viola, R. (2002). Biotechnological approaches for L-ascorbic acid production. Trends Biotechnology, 20, 299-305. http://dx.doi.org/10.1016/S0167-7799(02)01991-1

Hucker, G. J. \& Conn, H. J. (1923). Method of gram staining. New York Agricultural Experiment Station Technical Bulletin, 93, 3-37.

Huong, V. T. L., Malimas, T., Yukphan, P., Potacharoen, W., Tanasupawat, S. Loan, L. T. T., Tanticharoen, M. \& Yamada, Y. (2007). Identification of Thai isolates assigned to the genus Gluconobacter based on 16S-23S rDNA ITS restriction analysis. Journal of General and Applied Microbiology, 53, 133-142.

Karklinya, V. A., Veveris, A. J. \& Zhigure, D. R. (1982). Dihydroxyacetone measurement in the culture liquids of Acetobacter suboxydans. Prikladnaia Biokhimiia i Mikrobiologiya, 18, 262-265.

Kersters, K., Lisdiyanti, P., Komagata, K. \& Swings J. (2006). The family Acetobacteraceae: The genera Acetobacter, Acidomonas, Asaia, Gluconacetobacter, Gluconobacter, and Kozakia. In M. Dworkin, \& S. E. Falcow, E. Rosenberg, K.H. Schleifer, E. Stackebrands (Eds.). The Prokaryotes, 3rd edition, vol. 5 (pp. 163-200). New York: Springer. http://dx.doi.org/10.1007/0-387-30745-1_9

Kim, H. J, Kim, H. \& Shin, C. H. (1999). Conversion of D-sorbitol to L-sorbose by Gluconobacter suboxydans cells co-immobilized with oxygen-carriers in alginate beads. Process Biochemistry, 35, 243-248. http://dx.doi.org/10.1016/S0032-9592(99)00056-4

Kimura, M. (1980). A simple method for estimating evolutionary rates of base substitutions through comparative studies of nucleotide sequences. Journal of Molecular Evolution, 16, 111-120. http://dx.doi.org/10.1007/BF01731581

Kommanee, J., Akaracharanya, A., Tanasupawat, S., et al. (2008). Identification of Gluconobacter strains isolated in Thailand based on 16S-23S rRNA gene ITS restriction and 16S rRNA gene sequence analysis. Annals of Microbiology, 58, 741-747. http://dx.doi.org/10.1007/BF03175584 
Kommanee, J., Tanasupawat, S., Yukphan, P., et al. (2010). Gluconobacter nephelii sp. nov., an acetic acid bacterium in the $\alpha$-Proteobacteria. International Journal of Systematic and Evolutionary Microbiology, 61, 2117-2122. http://dx.doi.org/10.1099/ijs.0.026385-0

Malimas, T., Yukphan, P., Takahashi, M., et al. (2009). Gluconobacter japonicus sp. nov., an acetic acid bacterium in the alpha-Proteobacteria. Journal of General and Applied Microbiology, 55, 247-254. http://dx.doi.org/10.2323/jgam.55.247

Manzoni, M., Rollini, M. \& Bergomi, S. (2001). Biotransformation of D-galactitol to tagatose by acetic acid bacteria. Process Biochemistry, 36, 971-977. http://dx.doi.org/10.1016/S0032-9592(01)00137-6

Mishra, R., Jain, S.R. \& Kumar, A. (2008). Microbial production of dihydroxyacetone. Biotechnology Advances, 26, 293-303. http://dx.doi.org/10.1016/j.biotechadv.2008.02.001

Moonmangmee, D., Adachi, O., Ano, Y., et al. (2000). Isolation and characterization of thermotolerant Gluconobacter strains catalyzing oxidative fermentation at higher temperatures. Bioscience Biotechnology and Biochemistry, 64, 2306-2315. http://dx.doi.org/10.1271/bbb.64.2306

Saito, H. \& Miura, K. (1963). Preparation of transforming deoxyribonucleic acid by phenol treatment. Biochimica et Biophysica Acta, 72, 619-629. http://dx.doi.org/10.1016/0926-6550(63)90386-4

Saitou, N. \& Nei, M. (1987). The neighboring-joining method: a new method for reconstructing phylogenetic trees. Molecular Biology and Evolution, 4, 406-425.

Salusjärvi, T., Povelainen, M., Hvorslev, N., et al. (2004). Cloning of a gluconate/polyol dehydrogenase gene from Gluconobacter suboxydans IFO 12528, characterisation of the enzyme and its use for the production of 5-ketogluconate in a recombinant Escherichia coli strain. Applied Microbiology and Biotechnology, 65, 306-314.

Shinagawa, E., Mitshushita, K., Adachi, O. \& Ameyama, M. (1982). Purification and characterization of D-sorbitol dehydrogenase from membrane of Gluconobacter suboxydans. Agricultural Biology and Chemistry, 46, 135-141. http://dx.doi.org/10.1271/bbb1961.46.135

Skerman, V. B. D., McGowan, V. \& Sneath P. H. A. (1980). Approved Lists of Bacterial Names. International Journal of Systematic Bacteriology, 30, 225-420. http://dx.doi.org/10.1099/00207713-30-1-225

Tamaoka, J., Katayama-Fujimura, Y. \& Kuraishi, H. (1983). Analysis of bacterial menaquinone mixtures by high-performances liquid chromatography. Journal of Applied Bacteriology, 54, 31-36. http://dx.doi.org/10.1111/j.1365-2672.1983.tb01297.x

Tamura, K., Dudley, J., Nei, M. \& Kumar, S. (2007). MEGA4: molecular evolutionary genetics analysis (MEGA) software version 4.0. Molecular Biology and Evolution, 24, 1596-1599. http://dx.doi.org/10.1093/molbev/msm092

Tanaka, M., Murakami, S., Shinke, R. \& Aoki, K. (1999). Reclassification of the strains with low G+C

Tanasupawat, S., Thawai, C., Yukphan, P., et al. (2004). Gluconobacter thailandicus sp. nov., an acetic acid bacterium in the $\alpha$-Proteobacteria. Journal of General and Applied Microbiology, 50, 159-167. http://dx.doi.org/10.2323/jgam.50.159

Thompson, J. D., Gibson, T. J., Plewniak, F., Jeanmougin, F. \& Higgins D. G. (1997). The CLUSTAL X windows interface: flexible strategies for multiple sequence alignment aided by quality analysis tools. Nucleic Acids Research, 25, 4876-4882. http://dx.doi.org/10.1093/nar/25.24.4876

Trček, J. \& Teuber, M. (2002). Genetic and restriction analysis of the 16S-23S rDNA internal transcribed spacer regions of the acetic acid bacteria. FEMS Microbiology Letters, 208, 69-75.

Yamada, Y., Aida, K. \& Uemura T. (1968). Distribution of ubiquinone 10 and 9 in acetic acid bacteria and its relation to the classification of genera Gluconobacter and Acetobacter, especially of so-called intermediate strain. Agricultural Biology and Chemistry, 32, 786-788. http://dx.doi.org/10.1271/bbb1961.32.786

Yamada, Y., Hosono, R., Lisdyanti, P., et al. (1999). Identification of acetic acid bacteria isolated from Indonesian sources, especially of isolates classified in the genus Gluconobacter. Journal of General and Applied Microbiology, 45, 23-28. http://dx.doi.org/10.2323/jgam.45.23

Yamada, Y., Okada, Y. \& Kondo, K. (1976). Isolation and characterization of polarly flagellated intermediate strains in acetic acid bacteria. Journal of General and Applied Microbiology, 22, 237-245. http://dx.doi.org/10.2323/jgam.22.237 
Yukphan, P., Malimas, T., Lundaa, T., et al. (2010). Gluconobacter wancherniae sp. nov., an acetic acid bacterium from Thai isolates in the $\alpha$-Proteobacteria. Journal of General and Applied Microbiology, 56, 67-73. http://dx.doi.org/10.2323/jgam.56.67

Yukphan, P., Malimas, T., Muramatsu, Y., et al. (2004). Re-identification of Gluconobacter strains based on restriction analysis of $16 \mathrm{~S}-23 \mathrm{~S}$ rDNA internal transcribed spacer regions. Journal of General and Applied Microbiology, 50, 189-195. http://dx.doi.org/10.2323/jgam.50.189

Table 1. Isolation and identification of acetic acid bacteria producing dihydroxyacetone (96 h incubation) and L-sorbose (48 $\mathrm{h}$ incubation) assigned to the genus Gluconobacter

\begin{tabular}{|c|c|c|c|c|}
\hline \multirow{2}{*}{ Group and isolate } & \multirow{2}{*}{ Source } & \multirow{2}{*}{ Province } & \multicolumn{2}{|c|}{ Production of } \\
\hline & & & DHA (g/l) & L-sorbose $(\mathrm{g} / \mathrm{l})$ \\
\hline \multicolumn{5}{|l|}{ Group 1 (G. frateurii) } \\
\hline PHD-30 & Longan $^{2}$ & Trad & 25.43 & 39.68 \\
\hline PHD-31 & Longan $^{2}$ & Trad & 28.02 & 38.54 \\
\hline PHD-66 & Pum melo $^{2}$ & Ubon & 33.12 & 36.58 \\
\hline PHD-67 & Pum melo $^{2}$ & Ubon & 30.08 & 33.89 \\
\hline \multicolumn{5}{|c|}{ Group 2 (G. japonicus) } \\
\hline PHD-28 & Longan $^{2}$ & Changmai & 25.33 & 25.44 \\
\hline PHD-29 & Longan $^{2}$ & Changmai & 28.22 & 26.31 \\
\hline \multicolumn{5}{|c|}{ Group 3 (G. thailandicus) } \\
\hline PHD-11 & Jackfruit $^{2}$ & Nongkhai & 32.44 & 28.96 \\
\hline PHD-21 & Langsat $^{2}$ & Chantaburi & 36.58 & 30.28 \\
\hline PHD-22 & Langsat $^{2}$ & Chantaburi & 25.24 & 33.58 \\
\hline PHD-36 & Mango $^{2}$ & Bangkok & 28.32 & 35.42 \\
\hline PHD-39 & Mangosteen $^{2}$ & Trad & 31.2 & 28.19 \\
\hline PHD-40 & Mangosteen $^{2}$ & Trad & 27.65 & 22.14 \\
\hline \multicolumn{5}{|l|}{ Group 4 (G. oxydans) } \\
\hline PHD-10 & Jackfruit $^{2}$ & Nongkhai & 28.45 & 19.56 \\
\hline PHD-19 & Kaffir lime $^{2}$ & Khon Kaen & 32.32 & 18.45 \\
\hline PHD-20 & Kaffir lime $^{2}$ & Khon Kaen & 35.44 & 16.44 \\
\hline PHD-27 & Longan $^{2}$ & Changmai & 42.52 & 28.28 \\
\hline PHD-41 & Mangosteen $^{2}$ & Trad & 33.56 & 25.33 \\
\hline PHD-43 & Musk-melon $^{2}$ & Bangkok & 37.58 & 15.77 \\
\hline PHD-55 & Papaya $^{2}$ & Phuket & 32.78 & 20.89 \\
\hline PHD-59 & Petunia $^{1}$ & Chonburi & 40.33 & 25.56 \\
\hline PHD-60 & Petunia $^{1}$ & Chonburi & 39.69 & 23.12 \\
\hline PHD-81 & Sapodilla $^{2}$ & Trad & 35.36 & 20.96 \\
\hline PHD-82 & Sapodilla $^{2}$ & Trad & 40.12 & 29.36 \\
\hline PHD-88 & Strawberry $^{2}$ & Trad & 28.42 & 26.33 \\
\hline
\end{tabular}

${ }^{1}$ Flower, ${ }^{2}$ fruit. 
Table 2. Differential characteristics of isolates assigned to the genus Gluconobacter

\begin{tabular}{|c|c|c|c|c|c|c|c|c|}
\hline Characteristics & G1 & $G f$ & $\mathrm{G} 2$ & Gja & G3 & $G t$ & G4 & Go \\
\hline \multicolumn{9}{|l|}{ Oxidation of } \\
\hline Acetate & - & - & - & - & - & - & - & - \\
\hline Lactate & - & - & - & - & - & - & - & - \\
\hline Water soluble brown pigment & - & - & - & - & - & - & - & - \\
\hline Glutamate agar & - & - & - & - & - & - & - & - \\
\hline Mannitol agar & + & + & + & + & + & + & + & + \\
\hline \multicolumn{9}{|l|}{ Production of } \\
\hline 2-Keto-D-gluconate & + & + & + & + & + & + & + & + \\
\hline 5-Keto-D-gluconate & + & + & + & + & + & + & + & + \\
\hline 2,5-Diketo-D-gluconate & - & - & - & - & - & - & - & - \\
\hline Major quinone & Q-10 & Q-10 & Q-10 & Q-10 & Q-10 & Q-10 & Q-10 & Q-10 \\
\hline \multicolumn{9}{|l|}{ Acid production from } \\
\hline meso-Erythritol & $\mathrm{W}$ & $\mathrm{W}$ & + & + & $+(\mathrm{w} 2)$ & + & $+(\mathrm{w} 5)$ & + \\
\hline Maltose & $\mathrm{w}(-2)$ & w & - & - & $\mathrm{w}(-2)$ & $\mathrm{w}$ & + & + \\
\hline Raffinose & $+(\mathrm{w} 2)$ & + & + & + & $\mathrm{W}$ & $\mathrm{W}$ & $\mathrm{W}$ & $\mathrm{W}$ \\
\hline $\mathrm{DNA} \mathrm{G}+\mathrm{C} \mathrm{mol} \%$ & 55.2 & $55.1^{*}$ & 56.2 & $56.4^{*}$ & 57.2 & $55.8^{*}$ & 60.2 & $60.3^{*}$ \\
\hline
\end{tabular}

Gf, G. frateurii NBRC $3264^{\mathrm{T}}$; G1, Group 1 (four isolates); Gja, G. japonicus NBRC $3271^{\mathrm{T}}$; G2, Group 2 (two isolates); Gt, G. thailandicus BCC 14116 ${ }^{\mathrm{T}}$; G3, Group 3 (six isolates); Go, G. oxydans NBRC 14819 ${ }^{\mathrm{T}}$; G4, Group 4 (twelve isolates); +, positive; w, weakly positive; -, negative; Number in parentheses indicate the isolates showing the reaction. ${ }^{*}$ Data cited from Malimas et al., $2009 \mathrm{~b}$. 


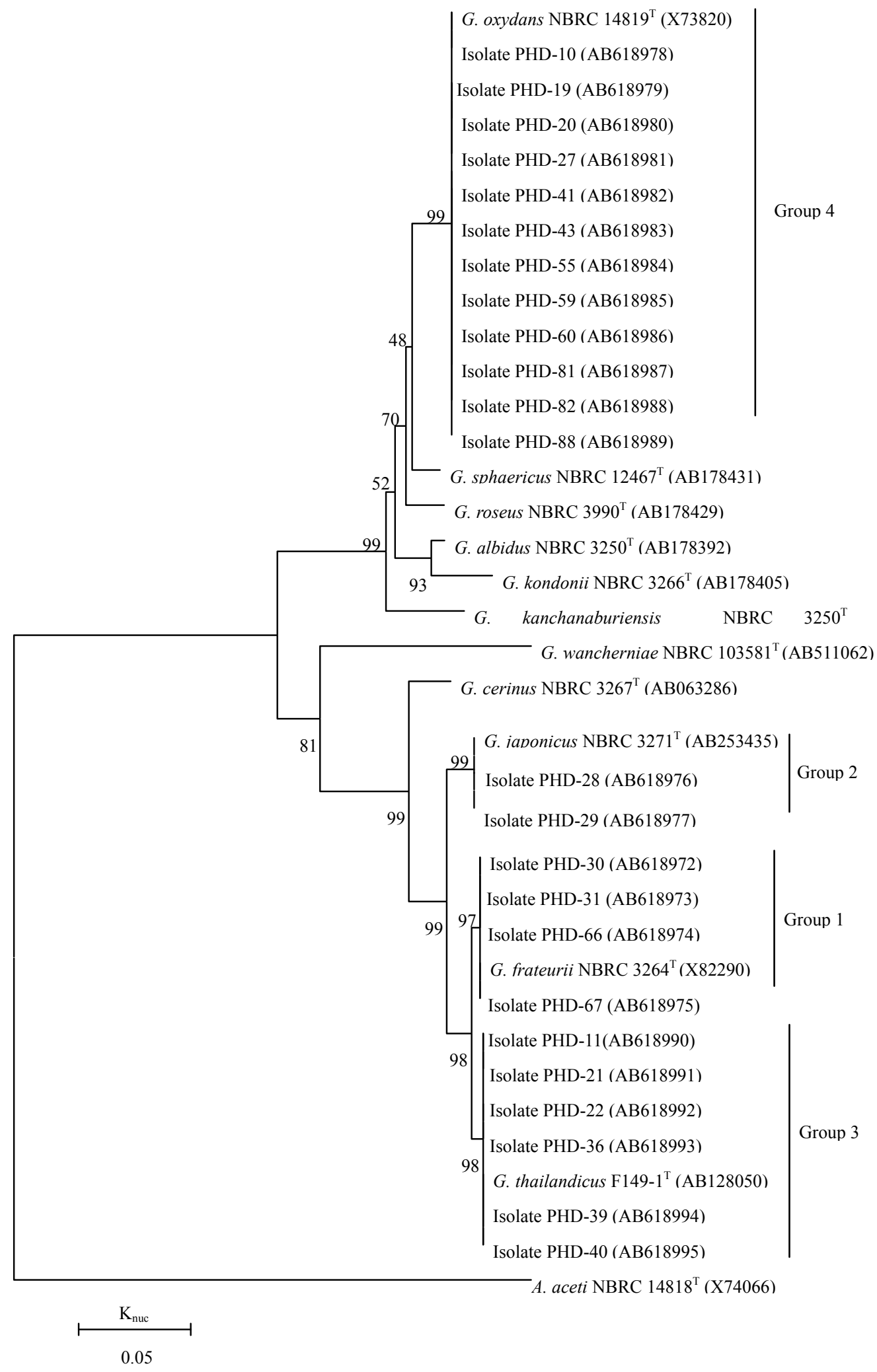

Figure 1. Phylogenetic relationships of isolates of Groups 1 to 4 based on 16S-23S rRNA gene ITS sequences. The phylogenetic tree was constructed by the neighbor-joining method. Numbers at nodes indicate bootstrap percentages derived from 1,000 replications 
(a)

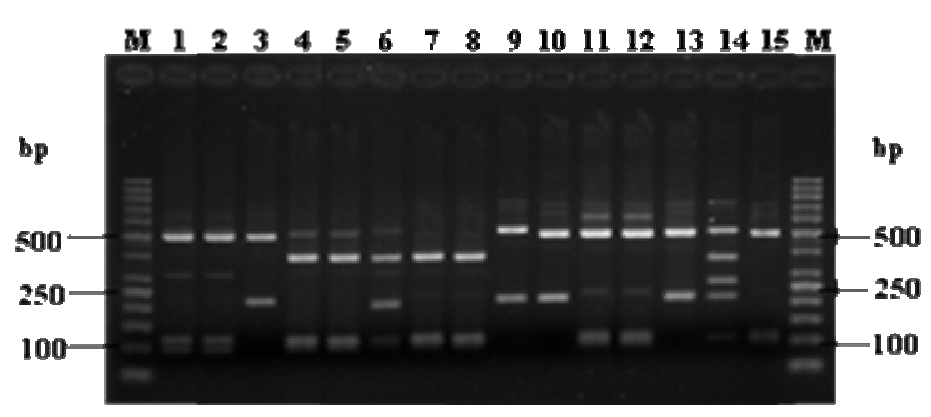

(b)

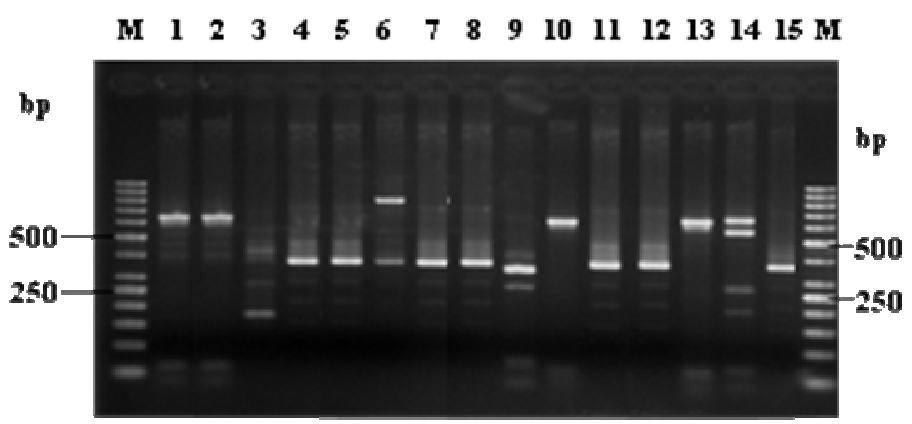

(c)

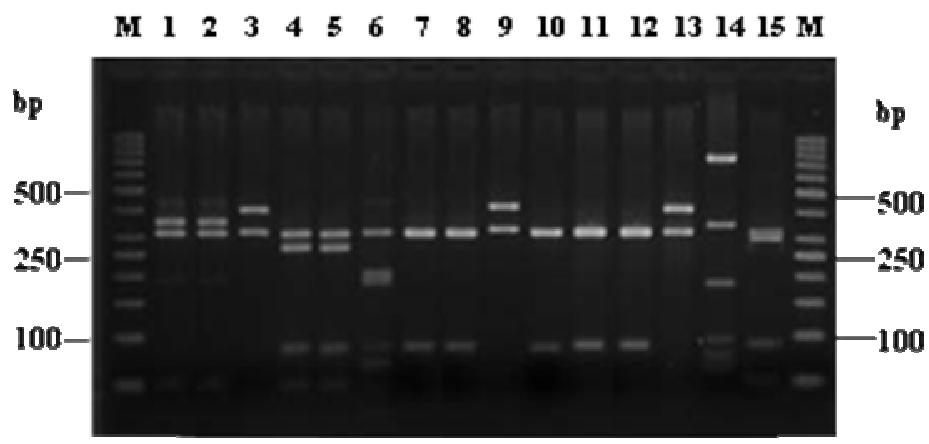

Figure 2. Restriction analysis of 16S-23S rRNA gene ITS PCR products of isolates by digestion with Bst NI (a), $M b o I I(b)$ and $M b o I(c)$

1, G. oxydans NBRC $14819^{\mathrm{T}}$; 2, isolate PHD-10 (Group 4); 3, G. cerinus NBRC $3267^{\mathrm{T}}$; 4, G. frateurii NBRC $3264^{\mathrm{T}}$; 5, isolate PHD-30 (Group 1); 6, G. albidus NBRC $3250^{\mathrm{T}} ; 7$, G. thailandicus BCC $14116^{\mathrm{T}}$; 8, isolate PHD-11 (Group 3); 9, G. kondonii NBRC 3266 ${ }^{\mathrm{T}}$; 10, G. roseus NBRC $3990^{\mathrm{T}}$; 11, G. japonicus $\mathrm{NBRC} 3271^{\mathrm{T}}$; 12 , isolate PHD-28 (Group 2); 13, G. sphaericus NBRC $12467^{\mathrm{T}}$; 14, G. kanchanaburiensis BCC $15889^{\mathrm{T}}$; 15, G. nephelii NBRC $106061^{\mathrm{T}}$ [15]; M, 50-bp DNA marker. 


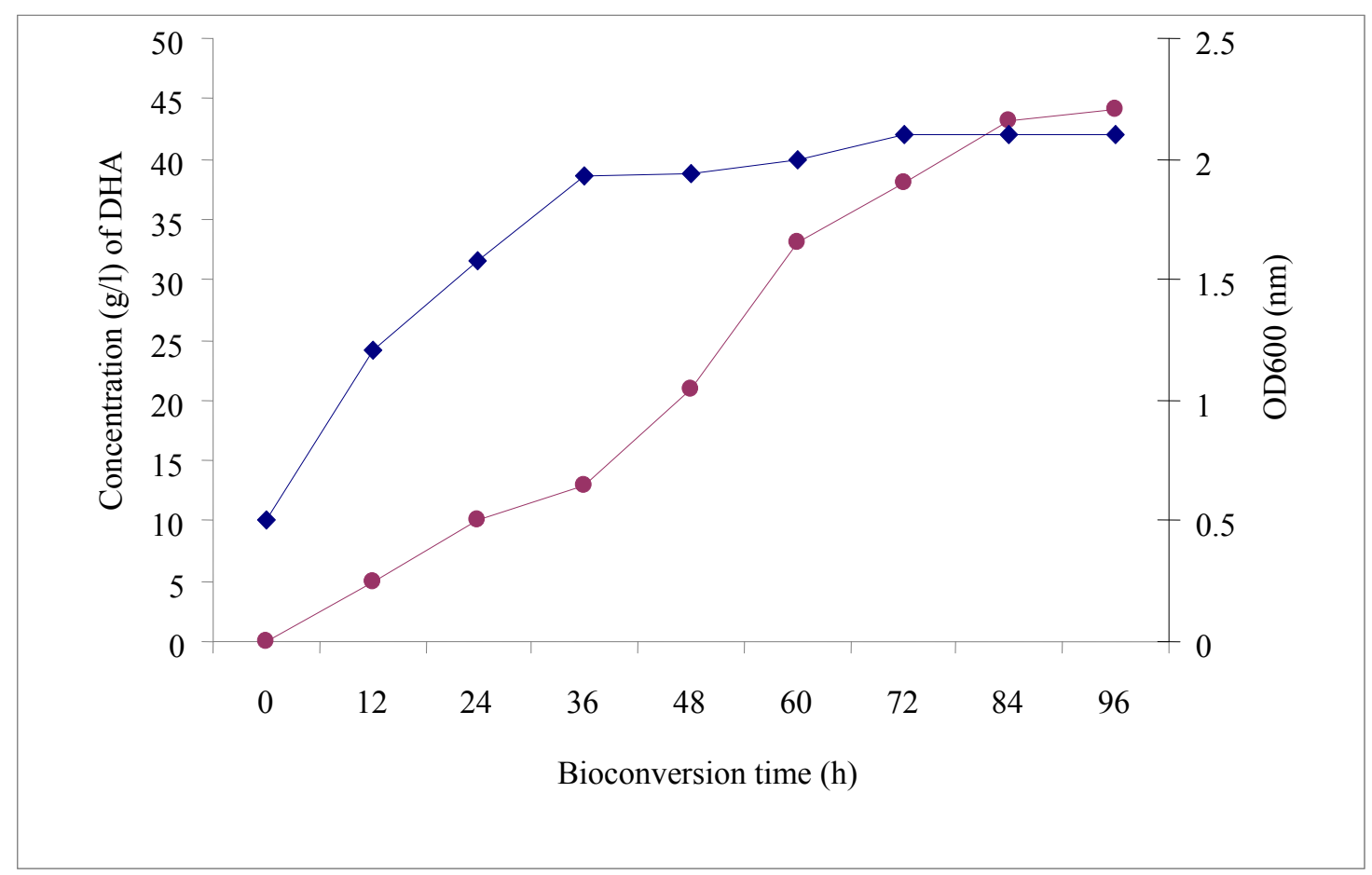

Figure 3. Time-courses of DHA production and growth of G. oxydans isolate PHD-27

$$
\text { Growth (•); DHA (•) }
$$

